\title{
Review of laboratory and clinical studies of olestra, a nonabsorbable lipid
}

\author{
Carolyn m Bergholz, PhD, Ronald J Jandacek, PhD, Alan BR Thomson, MD, PhD
}

CM BERGHOLZ, RJ JANDACEK, ABR THOMSON. Review of laboratory and clinical studies of olestra, a nonabsorbable lipid. Can J Gastroenterol 1991;5(4):137-146. The classical understanding of fat digestion and absorption is provided as background for a review of research on olestra, a triglyceridederived lipid that is not digested or absorbed from the intestinal lumen. Olestra (formerly 'sucrose polyester') is the generic name proposed for the mixture of the hexa, hepta and octa long chain fatty acid esters of sucrose. Olestra has the physical properties of fat and can therefore function as a zero calorie fat replacement in roods. The fate and effects of olestra in the gastrointestinal tract have been extensively investigated in animals and humans. Evidence from a variety of studies shows that olestra is not digested or absorbed and is not metabolized by colonic microflora. Feeding studies in five different species of animals show that olestra is nontoxic and noncarcinogenic, and causes no morphological changes in any tissues of the gastrointestinal tract. Consumption of olestra foods does not alter gastric emptying, transit through the small and large bowel, bile acid physiology, bowel function, or fecal $\mathrm{pH}$, water and electrolytes. Nutritional research shows no effect on absorption of macronutrients. Highly lipophilic materials such as cholesterol and vitamin $\mathrm{E}$ have the potential to partition into olestra, thereby decreasing their solubilization in intestinal micelles and subsequent absorption. Clinical research shows a modest reduction in serum cholesterol and vitamin E levels. The effect on vitamin $E$ absorption can be offset by supplementation of olestra with vitamin $\mathrm{E}$. The status of vitamins $\mathrm{D}$ and $\mathrm{K}$ and absorption of lipophilic drugs are not altered by daily consumption of $18 \mathrm{~g}$ olestra. Although serum retinol levels are not reduced, additional research is focusing on effects of olestra on hepatic stores of vitamin A to assess the appropriateness of supplementation. Using olestra to reduce the amount of fat in high fat foods, without affecting other nutrients, should contribute to a diet lower in energy from fat and higher in energy from carbohydrate. (Pour résumé, voir page 138)

Key Words: Fat substitute, Nonabsorbable lipid, Olestra

Division of Gastroenterology, University of Alberta, Edmonton, Alberta; and Procter \& Gamble Company, Cincinnati, Ohio, USA

Correspondence and reprints: Dr KD Lawson. The Procter \& Gamble Company, Winton Hill Technical Center, 6071 Center Hill Road, Cincinnati. OH 45224, USA. Telephone (513) $634-6700$

Received for publication May 3, 1991. Accepted June 11, 1991
T HERE HAVE BEEN NUMEROUS SUCcinct and scholarly reviews published recently on lipid absorption (1-9). It was over 15 years ago that Dietschy of Dallas, Texas (10-12) formulated the now classical, simple and logical approach to understanding the steps involved in lipid digestion and absorption, including the role of the pancreas in the secretion of lipases, the role of the liver in the secretion of bile acids needed for micellar solubilization, and the role of the enterocytes of the jejunal mucosa in the uptake, esterification and synthesis of lipoproteins incorporated into chylomicrons (Figure 1).

Chylomicrons cross the basolateral membrane of the enterocyte and enter first the lymphatics and then the blood. stream. As a result of the hydrolysis of dietary lipids, mixed micelles are formed with bile salts, solubilizing the lipolytic products and delivering fatty acids, monoglycerides, cholesterol, phospholipids and other lipophiles to the aqueous interface at the brush border membrane (BBM). Nutrients may cross the $\mathrm{BBM}$ through pores via carrier mediation (with or without energy expenditure), through the bulk lipid phase, or between cells. The classical consideration is one in which lipid uptake occurs by passive diffusion through the intestinal BBM. However, before lipolytic products can traverse the 


\section{Tour d'horizon des études cliniques et de laboratoire portant sur l'olestra - Lipide non assimilable}

RESUME: La compréhension classique du mécanisme de digestion et d'absorption des graisses fournit le cadre de ce tour d'horizon de la recherche consacrée à l'olestra, un lipide dérivé des triglycérides qui n'est ni digéré ni absorbé dans la lumière intestinale. L'olestra, anciennement appelé "sucrose polyester", est le nom générique qui désigne le mélange d'acides gras à chaîne longue/esters de sucrose. L'olestra a les caractéristiques physiques des graisses et peut donc servir de substitut alimentaire exempt de calorie. Le sort et les effets de l'olestra dans les voies digestives ont fait l'objet d'études exhaustives chez l'animal et l'être humain. Les résultats provenant de divers essais démontrent que l'olestra n'est ni digéré ni absorbé et qu'il n'est pas métabolisé par la microflore colique. Des études portant sur l'administration du produit chez cinq espèces animales différentes montrent que l'olestra n'est ni toxique ni carcinogène et qu'il n'entraîne aucun changement morphologique au niveau des tissus de l'appareil gastro-intestinal. La consommation d'aliments à base d'olestra ne modifie ni la vidange gastrique, ni le transit au niveau du grêle ou du gros intestin, ni les caractères physiologiques des acides biliaires, ni la fonction intestinale, ni le $\mathrm{pH}$, la teneur en eau ou l'ionogramme des matières fécales. La recherche en nutrition ne révèle aucun effet sur l'absorption des macronutriments. Les produits fortement lipophiles tels que le cholestérol et la vitamine E peuvent se scinder dans l'olestra, ce qui réduit leur solubilité dans les micelles intestinales et leur absorption subséquente. La recherche clinique montre une faible réduction de la cholestérolémie et des taux sériques de vitamine $E$. Les effets sur l'absorption de la vitamine E peuvent être corrigés par un apport complémentaire de vitamine E. La présence des vitamines $\mathrm{D}$ et $\mathrm{K}$, et l'absorption des médicaments lipophiles, n'est pas perturbée par la consommation quotidienne de $18 \mathrm{~g}$ d'olestra. Bien que les taux sériques de rétinol ne soient pas réduits, des essais supplémentaires étudient les effets de l'olestra sur les réserves hépatiques de vitamine A afin d'évaluer le bien-fondé d'un apport complémentaire éventuel. L'utilisation de l'olestra permet de réduire la teneur en graisses des aliments hyperlipidiques sans affecter les autres nutriments; elle devrait contribuer à réduire l'apport énergétique d'origine lipidique et à augmenter l'énergie provenant des hydrates de carbone.

membrane, the lipids must first pass through the unstirred water layer.

The unstirred water layer represents a series of lamellae of poorly stirred water through which nutrients must pass from the bulk phase across the BBM. Its resistance is determined by the thickness and surface area of the unstirred water layer, as well as by the diffusion coefficient of the nutrient.
The net effect of the unstirred water layer is to reduce the concentration of solute between the higher values seen in the intestinal lumen and the lower values seen at the aqueous-BBM interface. This latter concentration is the value 'seen' by the membrane and its carriers. Estimates of thickness of the unstirred water layer vary depending on site and experimental preparation. For example, the thickness of the unstirred water layer in the dog intestine is approximately $500 \mu \mathrm{m}$, a large value compared with the height of the villus (200 to $500 \mu \mathrm{m})$, the glycocalyx $(0.1$ to 0.5 $\mu \mathrm{m}$ ), the height of the microvillus (1 $\mu \mathrm{m})$ or the thickness of the BBM itself $(0.1 \mu \mathrm{m})$. The thickness of the unstirred water layer may vary along the length of the villus, as will its surface area. For example, the thickness and surface area of the unstirred water layer may be lower in the upper versus the lower portions of the villus. When the bulk phase in the intestinal lumen is stirred, the thickness of the unstirred water layer falls, its surface area will rise, and the net effect is a fall in un. stirred water layer resistance. However, even with vigorous stirring the effective surface area of the unstirred layer is much less than the surface area of the villi or the microvilli.

The functional surface area of the microvillus membrane is another factor in nutrient absorption. For example, for amino acids, glucose and certain lipids, most uptake occurs in the upper onethird of the villus. It would also appear that the villus tip is more acidic than

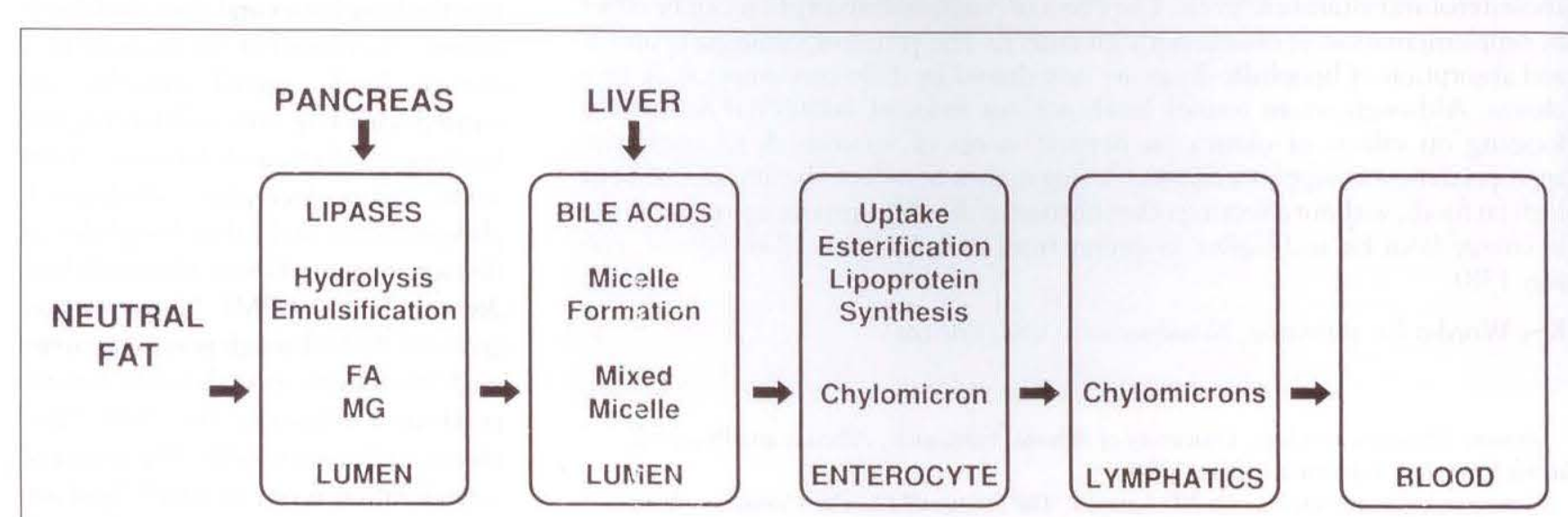

Figure 1) Logical approach to understanding the steps involved in lipid digestion and absorption 
TRIGLYCERIDE (Glycerol with Fatty Acids)

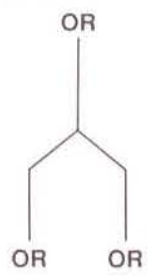

$\mathrm{R}=\mathrm{FATTY}$ ACID $\left(\mathrm{CH}_{3}-\mathrm{CH}_{2}\right)_{\mathrm{n}}-\stackrel{\mathrm{O}}{\mathrm{C}}-\mathbf{r}$

Figure 2) Comparison of the structure of a triglyceride molecule with that of olestra. O Oxygen

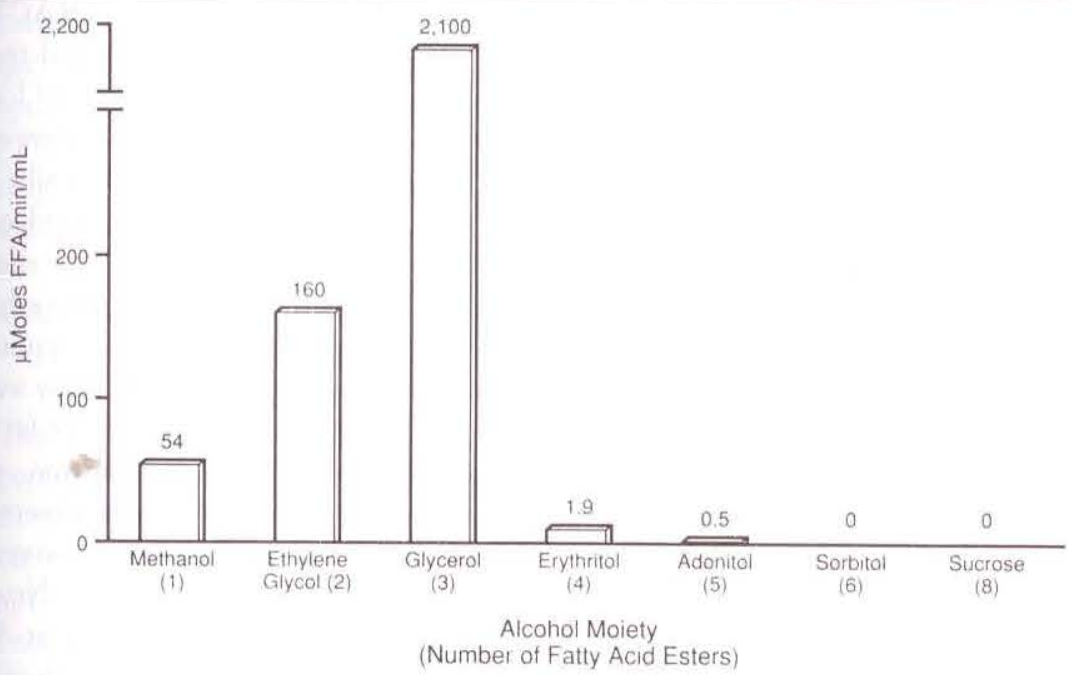

Figure 3) Relative rates of hydrolysis of the complete oleate esters of a series of polyol moieties incubated at $27^{\circ} \mathrm{C}$ with fluid from the rat common bile-pancreatic duct and maintained at $\mathrm{pH} 9$. The rate of hydrolysis is reported as $\mu \mathrm{mol}$ free fatty acid (FFA) released per min per $\mathrm{mL}$ of enzyme preparation

the villus base. For fatty acids, protonation reduces their solubility in micelles but also increases their preferential partitioning into the BBM.

Lipids solubilized in micelles do not enter the enterocytes with intact micelles; instead, there is evidence that lipid absorption occurs predominantly through partitioning from the micelle into an obligatory aqueous phase and then across the BBM. Under experimental conditions some uptake may occur directly from micelles into the BBM. It has also recently been suggested that there may be a distinct microvillus membrane fatty acid binding protein which might be responsible for very early uptake of long chain fatty acids and cholesterol. This is suggested by studies showing that at very low concentrations of lipid, there is a curvilinear relationship between substrate concentration and uptake. Although there are many possible explanations for this nonlinear relationship, there is other evidence that uptake of one fatty of a second fatty acid, by changes in unstirred water layer resistance or $\mathrm{pH}$, or by removal of sodium.

Resistance of the unstirred water layer also varies in health and disease, representing one of several mechanisms by which the intestine can acid may be inhibited by the presence adapt nutrient transport. There is no doubt that the intestine is capable of adaptation, with increases or decreases in the uptake of lipids as well as other nutrients. This adaptive process may involve alterations in transport rate, Michaelis constant, or permeability and/or morphology of the intestine. This adaptation can normalize lipid uptake and thus benefit the individual.

Let us now consider a major, potentially important innovation in nutrition, the development of olestra, a nonabsorbable lipid that could be used to replace fat in a wide variety of foods.

\section{BACKGROUND}

Olestra is the generic name for the mixture of hexa-, hepta- and octaesters of sucrose formed with long chain fatty acids isolated from vegetable oil. It is the subset of sucrose polyesters which is not hydrolyzed by pancreatic lipase and is therefore not absorbed. As shown in Figure 2, olestra has a sucrose core in place of the glycerol core of triglyceride and is esterified with six to eight fatty acids rather than three. Steric hindrance due to the larger bulk of the olestra molecule apparently accounts for the lack of hydrolysis by lipases. In contrast to the higher esters, the mono-, di- and triesters of sucrose are fully digested and absorbed and are used in foods as emulsifiers and to coat fruit.

The discovery of olestra resulted from research on lipid digestion and absorption. FH Mattson and RA Volpenhein at Procter \& Gamble (13) synthesized a series of polyols fully esterified with one to eight oleic acids, and investigated the rate of hydrolysis of each by pancreatic lipolytic enzymes in vitro. As shown in Figure 3, when a mixture of rat pancreatic and bile fluid was added to esterified polyols, there was a sharp decrease in the rate of hydrolysis of polyols having more than three fatty acid esters. No measurable hydrolysis was observed for sorbitol esterified with six fatty acids or sucrose esterified with eight fatty acids. Fat balance and absorption studies in thoracic duct-cannulated rats showed that sucrose octa-oleate was not $a b$ sorbed $(14,15)$, providing convincing 
evidence that hydrolysis of lipids is a prerequisite for absorption.

Technically, olestra can be used interchangeably with fat in a wide variety of foods (16). Because its physical properties are similar to those of conventional triglycerides, it can be blended with conventional fats and used in cooking, baking or deep frying. Foods made with olestra have the same taste and texture as those made with full calorie fats. Similarly, the heating and storage stabilities are comparable to those of conventional fat.

Procter \& Gamble has filed a 'Food Additive Petition' with the US Food and Drug Administration (FDA) and a 'Food Additive Submission' with the Canadian Health Protection Branch requesting approval to use olestra to replace $100 \%$ of the oil used in preparing savory snacks such as corn and potato chips. Additional uses will require new petitions to be filed and approved.

The submissions include reports of over 100 laboratory and animal studies and controlled clinical investigations involving thousands of subjects. Results or extensive research on absorption, chronic toxicity, carcinogenicity, reproduction, nutrition, and gastrointestinal physiology support the safety of olestra in foods $(17-23)$. Because olestra is not digested and not absorbed, the gastrointestinal tract is the only organ system exposed to olestra.

Lipophilic materials can partition into this unabsorbed lipid; thus olestra has the potential to decrease the absorption of lipophilic molecules by competing with the mixed micelles for them (24).

A review of the research pertaining to the fate and effects of olestra in the gastrointestinal tract will provide an overview of the biological properties of olestra. The results of this research provide evidence that olestra is not absorbed or metabolized in the gastrointestinal tract and does not affect gastrointestinal morphology, gastric emptying, pancreatic response, bile acid physiology or bowel function. These data are reviewed along with studies on the potential for olestra to

TABLE 1

Olestra long term animal studies

\begin{tabular}{cccc}
\hline Reference & Species & Duration & $\%(w / w)$ of diet \\
\hline 20 & Rat & 24 months & $0,1,5,9$ \\
20 & Rat & 24 months & 0,9 \\
23 & Dog & 20 months & $0,5,10$ \\
22 & Monkey & 44 months & 0,8 \\
\hline
\end{tabular}

affect absorption of nutrients and organic toxicants.

\section{OLESTRA ABSORPTION AND METABOLISM}

The lack of absorption of olestra is an important consideration in the assessment of the safety of olestra and its effects on the gastrointestinal tract. Because olestra is not hydrolyzed, it does not form mixed micelles with bile salts and is therefore not transported to the BBM of the enterocytes where fatty acids and monoglycerides are absorbed. It is excreted unchanged in the feces, indicating that it is not metabolized by microorganisms in the colon (17).

Evidence that olestra is not metabolized or absorbed comes from animal studies with radiolabelled olestra, fat balance studies in animals and humans, and analysis of tissues from monkeys and rats in long term feeding studies $(14,17,19)$. Since olestra is not absorbed, it was necessary to use intravenous injection of radiolabelled olestra to determine which organs would take up olestra and whether it would be metabolized if it were absorbed. The results showed that intravenously administered olestra was rapidly taken up primarily by the liver and then excreted slowly, intact, into the bile with a half-life of about five days (19; RJ Jandacek, Procter \& Gamble, unpublished data). Olestra entered the intestinal lumen in bile and was excreted unchanged from the body. When sensitive chromatographic methods were used to analyze liver tissue from rats fed olestra for two years or monkeys fed olestra for 29 months, no olestra was detected, indicating that it does not accumulate in tissues (19). The chromatographic methods would have detected $10^{-5}$ to $10^{-6} \%$ of the total amount of olestra consumed by the animals. Recent studies using ${ }^{14} \mathrm{C}$ - labelled olestra also showed detection of radiolabel in lipid extracts of liver from rats only near the limits of detection of approximately $4 \times 10^{-4} \%$ of the administered dose (KW Miller, Procter $\&$ Gamble, unpublished data).

\section{MORPHOLOGICAL EVALUATION OF THE GASTROINTESTINAL TRACT}

Tissues of the gastrointestinal tract taken from animals in short and long term feeding studies (Table 1) were examined grossly and microscopically. In these studies there was no evidence that olestra caused any adverse effect detectable by clinical measures or histopathology. Special lipid staining techniques used in a 91 day study with rats showed no accumulation of fat in the intestinal wall. In addition, no treatment-related effects were observed in Peyer's patches of rats after two years (20). Analysis of mesenteric lymph nodes of monkeys fed olestra at $8 \%$ (w/w) of the diet for 29 months showed no accumulation of olestra (19).

\section{BOWEL FUNCTION}

A number of fecal parameters and other indicators of normal bowel func. tion were evaluated in animal and clinical investigations. Fecal lipid (other than olestra), water, electrolytes and $\mathrm{pH}$ were not affected by olestra. Frequency of bowel movement was normal, even after consumption of 50 $\mathrm{g} /$ day olestra (18). Scattered incidences of softer stools have been observed in animal (24) and human studies (17) with olestra. The soft stools result from the large amount of unaltered olestra excreted in the feces and do not represent a physiological response to olestra. Diarrhea was not observed. Some subjects who had problems with constipation considered this effect a benefit (17). 
High levels of liquid olestra used in some of the early studies produced spontaneous leakage of oil drops from the gastrointestinal tract. This problem was corrected by increasing the viscosity and melting point of olestra to preclude oil phase separation from fecal solids at body temperature. Scattered and transitory incidences of common gastrointestinal symptoms - such as flatulence, bloating and heartburn reported in early clinical studies, were associated with high doses (50 to greater than $100 \mathrm{~g}$ ) of liquid olestra in formula diets. Controlled clinical studies with reformulated olestra involving over 2000 subjects, both adults and children, showed no oil loss and no statistically significant difference in subjectively evaluated gastrointestinal symptoms following single or multiple day consumption of foods made with the higher melting olestra formulations versus triglyceride placebo controls.

\section{GASTRIC EMPTYING AND GASTROINTESTINAL TRANSIT TIME}

The effect of olestra on gastric emptying was investigated in clinical trials conducted by Cortot et al $(25,26)$. In the first clinical investigation, ${ }^{14} \mathrm{C}$-labelled olestra was validated as a nonabsorbable marker for the lipid phase. In a second study, olestra was used as a nonhydrolyzable lipid to study the mechanism of gastric emptying of the lipid phase. In addition to the radiolabelled olestra used as a marker, a total of $20 \mathrm{~g}$ olestra was administered via intragastric tube at four intervals during eating of a meal containing $4.7 \mathrm{~g}$ fat. Digested samples were collected through an indwelling multilumen duodenal tube at $10 \mathrm{~min}$ intervals. Most of the olestra was emptied in the first $2 \mathrm{~h}$ along with the water. Solids and fat were emptied over a period of $6 \mathrm{~h}$ as previously reported (26), suggesting that olestra did not delay its own emptying and did not interfere with response to signals from the products of fat digestion.

The effect of olestra on gastrointestinal transit was also measured in 30 healthy subjects using gamma scintigraphy (unpublished data). Olestra

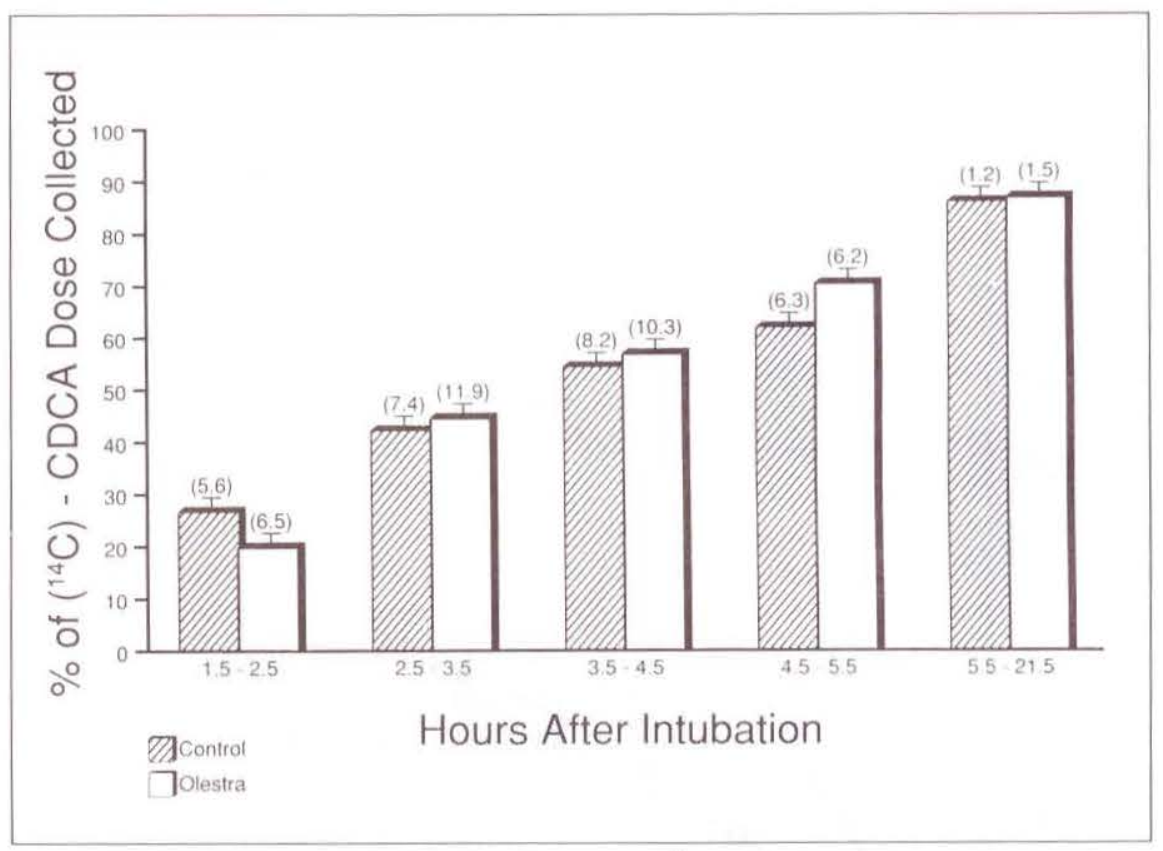

Figure 4) Cumulative percentage recovery in bile of ${ }^{14} \mathrm{C}$-chenodeoxycholic acid (CDCA) administered to rats by intubation followed by soybean oil or $50 / 50$ soybean oil/olestra. Numbers in parentheses are standard error measurements

$(7.5,15$ or $30 \mathrm{~g})$ included in a single, isocaloric and isolipid meal (breakfast) had no significant effect on gastric emprying, small bowel transit or large bowel transit, relative to high and low fat triglyceride control meals.

Olestra has also been shown not to stimulate a pancreatic response in rats (27). Tissue levels of pancreatic enzymes in rats fed olestra at $5 \%(\mathrm{w} / \mathrm{w})$ of the diet or $16 \%$ in combination with $4 \%$ hydrogenated palm oil for 28 days, resembled those in rats eating a low fat diet.

Results of these studies indicate that olestra is not perceived as a digestible fat by the gastrointestinal tract and does not interfere with the generation of, or response to, signals from other components of the diet.

\section{BILE ACIDS}

A number of studies were conducted to investigate the potential effects of olestra on bile acid physiology $(24,28$ 32). These studies included quantitative and qualitative evaluation of bile acid absorption and synthesis, and biliary and fecal bile acid profiles.

In a study that assessed bile acid absorption directly, bile duct-cannulated rats were administered ${ }^{14} \mathrm{C}$-chenode- oxycholic acid (CDCA) by intubation, followed by soybean oil in one group and 50/50 soybean oil/olestra in another group (22). Figure 4 shows the cumulative ${ }^{14} \mathrm{C}$ activity in the bile collected at intervals over $21.5 \mathrm{~h}$ after intubation. Administration of olestra with CDCA had no effect on the rate or amount of radiolabel absorbed. These results suggest that absorption of conjugated bile acids, the more common species in the intestine, would not be affected by olestra, since CDCA is one of the most lipophilic bile acids, and bile acids conjugated with glycine or taurine are more polar.

Bile acid synthesis and fecal excretion was examined in a 14 day study in which rats were fed soybean oil, liquid olestra at $8 \%(\mathrm{w} / \mathrm{w})$ of the diet, or solid olestra at $8 \%(w / w)$ of the diet along with $2 \%$ hardened palm oil in all groups (24). On day $8,{ }^{14} \mathrm{C}$-cholesterol was administered intravenously and feces were collected daily for the next seven days. Figure 5 shows the cumulative excretion of ${ }^{14} \mathrm{C}$ in the neutral and acidic steroid fractions. There was no effect of either olestra sample on the rate or total percentage of labelled fecal bile acids excreted (24). Olestra enhanced excretion of neutral steroids, as pre- 


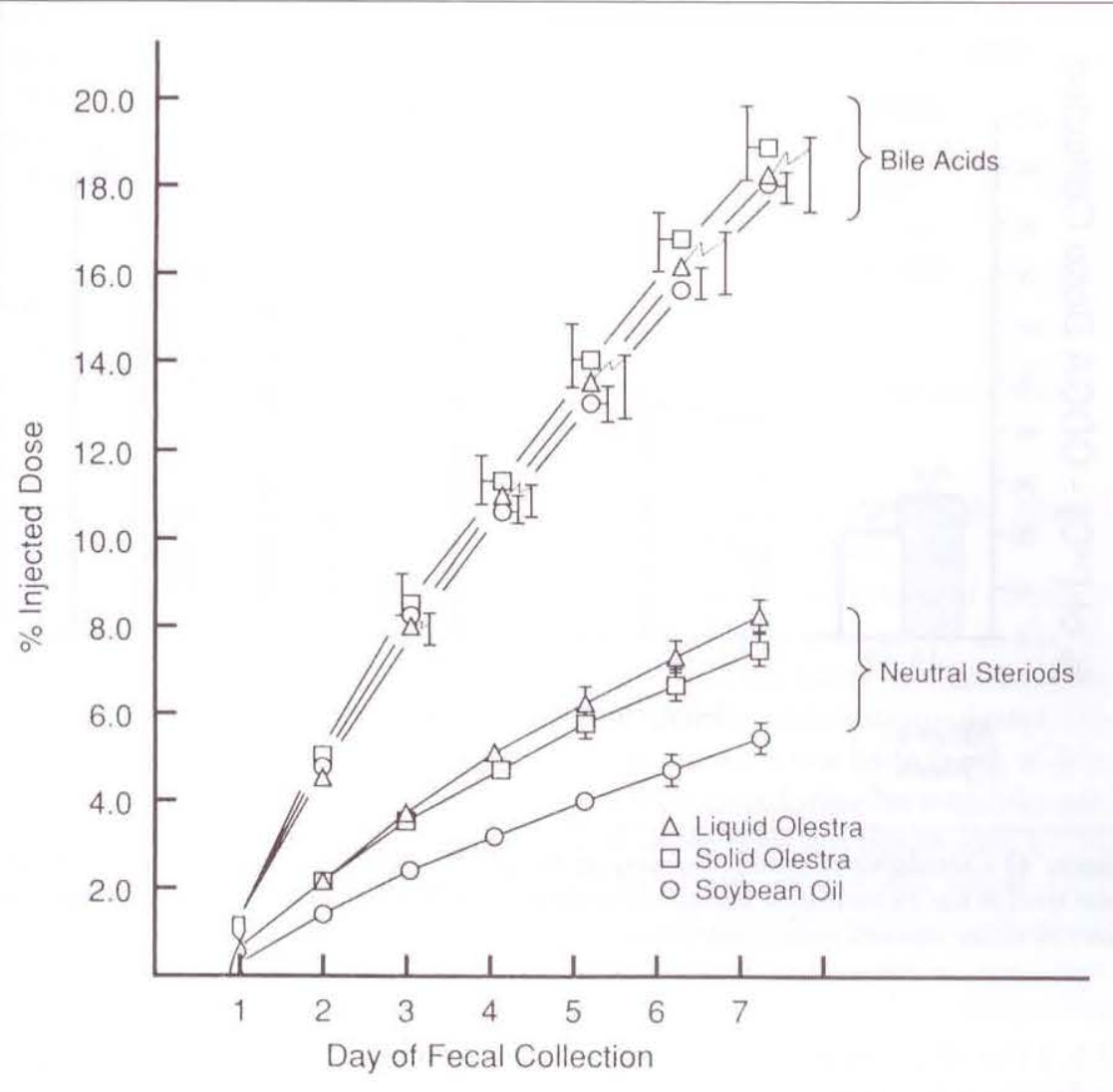

Figure 5) Cumulative excretion of ${ }^{14} \mathrm{C}$ in the neutral and acidic fecal steroid fractions in rats administered ${ }^{14} \mathrm{C}$-cholesterol intravenously on day 8 of a 14 day study in which rats were fed soybean oil, liquid olestra or solid olestra each blended $80 / 20$ with hardened palm oil. The olestra or soybean oil concentration was $8 \%(w / w)$ of the diet. Stools were collected on days 1 to 7 post injection of radiolabelled cholesterol

\section{TABLE 2}

\section{Fecal bile acid excretion of rats fed olestra at $5 \%(w / w)$ of the diet for two months}

\begin{tabular}{lcc}
\hline & \multicolumn{2}{c}{ Groups } \\
Bile acid & Control (mg/day) & Olestra (mg/day) \\
\hline Lithocholic & $0.4 \pm 0.08$ & $0.4 \pm 0.07$ \\
3b, 12-alpha-dihydroxycholanoic & $0.1 \pm 0.01$ & $0.2 \pm 0.05$ \\
Deoxycholic & $3.2 \pm 0.6$ & $2.5 \pm 0.3$ \\
3a, 12-beta-dihydroxycholanoic & $0.04 \pm 0.01$ & $0.02 \pm 0.002$ \\
Chenodeoxycholic & $10.4 \pm 1.2$ & $11.9 \pm 1.5$ \\
Ursodeoxycholic & $1.9 \pm 0.6$ & $1.6 \pm 0.2$ \\
Cholic & $0.4 \pm 0.06$ & $0.6 \pm 0.09$ \\
Beta-muricholic & $1.5 \pm 0.4$ & $1.8 \pm 0.3$ \\
Others & $0.7 \pm 0.09$ & $0.9 \pm 0.1$ \\
Total & 18.6 & 19.9 \\
\hline
\end{tabular}

Values given are mean \pm standard deviation for $n=5$

viously demonstrated using other methods $(28,29)$. In another study in which rats were fed olestra at $0 \%$ or $5 \%$ of the diet for two years, feces were collected for bile acid analysis over a 24 $\mathrm{h}$ period at one, two and 24 months of the study. Representative data are shown in Table 2. No significant difference was seen in the bile acid profile or the total amount excreted.

In a human study, 24 normal healthy male subjects were fed olestra in- creasing from 0 to $40 \mathrm{~g} /$ day for four 10 -day periods (30). Fecal samples were collected for five days at each dose. Analysis of fecal bile acids showed wide variability among subjects at baseline. With olestra, there was no significant difference in amounts of bile acids excreted, no dose response, and no consistent effect on bile acid composition. One subject showed a decrease in secondary bile acids, but the decrease showed no dose response with respect to olestra. In two other studies, in creases in bile acid excretion were reported for some subjects $(31,32)$. In these studies olestra intake was very high ( 50 to $90 \mathrm{~g} /$ day in liquid formula hypocaloric diets).

Bile was also collected from rats fed $5 \%$ olestra in the diet for five and 10 weeks. There was no difference in biliary bile acid profiles in olestra-fed and chow-fed animals. Bile was also sampled seven times over the course of one year in a study in which African green monkeys were fed olestra at $6 \%$ of the diet. Analysis of bile showed no effect on bile acid profile, pool size, bile composition or lithogenicity index relative to animals fed the basal diet. Crouse and Grundy (31) also reported that saturation of gallbladder bile in man was not adversely affected by ingestion of olestra $50 \mathrm{~g} /$ day for six weeks. If bile acid absorption were decreased by olestra, the biliary bile acid profile would show an increase in the proportion of primary bile acids due to an increase in synthesis by the liver.

\section{COLONIC MICROFLORA}

Fecal recovery of olestra from animals in long term feeding studies and from humans in clinical investigations indicates that olestra is not metabolized by colonic microflora. In vitro experiments also demonstrated that radiolabelled olestra was not metabolized by fecal microflora collected anaerobically from seven subjects who had consumed olestra for 30 days (33). Measurement of volatile fatty acids, lactic acid, and hydrogen and methane production in other in vitro experiments showed that olestra did not af fect microbial fermentation.

As discussed above, olestra did not 
affect fecal or biliary bile acid profiles, indicating no effect on microbial deconjugation and biotransformation of primary to secondary bile acids. At higher intakes a decrease in bioavailability of neutral sterol substrate due to partitioning into olestra decreases bioconversion by $0.6 \% / \mathrm{g}$ olestra among individuals with a microflora that metabolizes these substrates (29). Studies in animals and humans have also shown no effect of olestra on fecal nitrogen excretion, providing evidence that olestra does not affect microbial biomass. Since gut microflora play a critical role in colonic physiology, the lack of an effect of olestra on fecal water, electrolytes and $\mathrm{pH}$ provide additional evidence that olestra does not affect the colonic microflora.

\section{CHOLESTEROL ABSORPTION}

The absorption of cholesterol is decreased when olestra is included in the diet. This effect has been observed when the source of intestinal cholesterol is either exogenous (dietary) or endogenous (biliary or intestinal cell). The effect of olestra $14 \mathrm{~g} /$ day on cholesterol absorption was recently investigated in a crossover study among 20 healthy subjects who ingested radiolabelled cholesterol in butter and olestra-containing spread (34). During the olestra regimen, cholesterol absorption was $46.7 \pm 1.6 \%$ compared with $58.1 \pm 1.1 \%$ during the period of butter consumption. The difference was statistically significant.

As mentioned above and shown in Figure 5, olestra enhanced the excretion of neutral steroids in rats injected with ${ }^{14} \mathrm{C}$-labelled cholesterol (24). Since the animals in that study received a cholesterol-free diet, the observed increase in neutral steroid excretion reflected an effect of olestra on the re-absorption of cholesterol from an endogenous source, presumably originating in bile or intestinal cells.

The decrease in absorption of dietary cholesterol in the presence of olestra results from partitioning of cholesterol in foods into the olestra phase in the gastrointestinal tract, which retains a portion and carries it from the body. The effect on endo- genous cholesterol must, at least in part, involve the exchange of cholesterol from the aqueous system of bile into the olestra oil phase.

\section{MACRONUTRIENT ABSORPTION}

Since the primary function of the gastrointestinal system is the digestion and absorption of macro- and micronutrients, the potential for olestra interference with this function is an important area of investigation. Looking first at macronutrients, numerous studies in animals and humans have demonstrated that olestra does not affect the absorption of proteins, carbohydrates or fats $(20,21,23)$. Indirect evidence comes from results of long term feeding studies in rats (20) and dogs (23) and data from two generation reproduction study in rats (21). None of these studies showed any effect of olestra on the growth, development or longevity of the animals nor any clini$\mathrm{cal}$ indicator of health status. Studies have also been conducted specifically to assess the potential of olestra to affect absorption of each macronutrient.

In a study of absorption of oral glucose in rats, olestra did not affect the time to peak blood glucose concentration, the peak blood glucose concentration, or the area under the concentration-versus-time curve. Olestra has also been shown not to affect fasting blood sugar concentrations in rats, dogs and humans, further demonstrating that it does not interfere with carbohydrate absorption. For example, fasting blood glucose levels in patients with adult onset diabetes were unaffected by the ingestion of olestra 90 $\mathrm{g} /$ day for up to 50 days (32), providing evidence that carbohydrate absorption is unaffected by olestra.

Evidence that absorption of proteins and amino acids is unaffected by olestra comes from a variety of studies. Olestra, tested at up to $15 \%$ of diet by weight, had no effect on nitrogen balance measured in 28-day dog and 91-day rat feeding studies (FH Mattson, EJ Hollenbach, Procter \& Gamble, personal communication). In a study of rats dosed with radiolabelled methionine or phenylalanine in water followed by olestra or corn oil, there was no difference in the rate of recovery of ${ }^{14} \mathrm{C}$ in carbon dioxide, urine or feces (WB Gibson, Procter \& Gamble, personal communication). Since amino acids are not stored by the body and thus total body pools are small, differences in the rate of absorption will be readily reflected by differences in catabolic rates.

The similarity of radiolabelled carbon dioxide expiration with time between olestra-fed and control animals indicates that olestra did not affect either the rate of absorption or the overall disposition of amino acids. Measurement of fecal nitrogen in a human clinical study showed a mean excretion of $1.42 \pm 0.38 \mathrm{~g}$ per $24 \mathrm{~h}$ during a 10-day basal period and $1.37 \pm 0.27 \mathrm{~g}$ per $24 \mathrm{~h}$ with $50 \mathrm{~g} /$ day olestra in the diet (CJ Glueck, RW Fallat, University of Cincinatti, personal communication), providing further evidence that protein absorption is not affected by olestra consumption.

The lack of an effect of olestra on fat absorption was demonstrated in studies conducted in rats and humans in which the amount of fat egested was compared to the amount ingested $(14,17)$. In a representative clinical study Fallat et al (17) showed no difference in the percentage of fat absorbed with $50 \mathrm{~g} /$ day olestra, either added to the diet or replacing $50 \mathrm{~g}$ fat in the diet. Other studies measuring recovery of radiolabelled triolein in the lymph of thoracic duct-cannulated rats also showed that olestra did not alter fatty acid absorption to any meaningful extent (15). Analysis of liver tissue from rats fed a control diet or olestra at 5\% of the diet for two years showed only minor differences in fatty acid composition, not attributable to olestra (20).

When considered together, these results support the conclusion that olestra does not interfere to any meaningful extent with lipolysis of triglycerides or phospholipids, partitioning of products of lipolysis into the micellar phase, nor uptake of products by enterocytes.

Olestra did not affect total lipid, phosphatidylcholine or phosphatidyl ethanolamine levels in the liver and kidneys of rats fed olestra at $10 \%$ of diet 
for three weeks, indicating that olestra does not affect overall choline status.

\section{MINERAL ABSORPTION}

Olestra would not be expected to affect mineral absorption since minerals are not lipid soluble and since olestra does not saponify in the gastrointestinal tract. As expected, serum chemistries and analysis of fecal calcium and magnesium in long term studies in animals and in clinical studies have shown no difference between control and olestra groups.

\section{VITAMIN ABSORPTION}

Early animal studies showed that high levels of olestra could lower fatsoluble vitamin absorption (35). The potential to affect absorption of the fatsoluble vitamins depends on a number of factors, among them the lipid solubility of the vitamin and the amount of olestra in the diet. Data on vitamin status were collected in clinical studies in which the only consistent effect was a decrease in serum vitamin E levels to the low normal range $(17,31$, 32,36-39). A recent 16 week study showed a $6 \%$ decrease in serum vitamin $\mathrm{E}$ with daily ingestion of $18 \mathrm{~g} /$ day olestra (BP Koonsvitsky, Procter \& Gamble, unpublished data). Based on these data, supplementation of olestra with $\mathrm{D}$-alpha-tocopherol is proposed to maintain nutritional equivalence to vegetable oil, which is a significant source of vitamin $\mathrm{E}$ in the diet.

Additional clinical research has been conducted using large base sizes and state-of-the-art methods to ensure that the nutritional status of other fatsoluble vitamins will not be affected at the levels of olestra consumption expected for the uses proposed in the current regulatory submissions.

In an investigation of the effect of olestra on vitamin D status, 202 freeliving adults consumed $20 \mathrm{~g} /$ day of olestra in cookies for six weeks, as part of a diet supplemented with $760 \mathrm{iu} /$ day of vitamin $D_{2}$ in order to measure effects on absorption (40). Serum 25 hydroxy- $D_{2}$ levels rose from between 5.6 and $5.8 \mathrm{nmol} / \mathrm{L}$ at baseline to 39.0 and $31.7 \mathrm{nmol} / \mathrm{L}$ for the placebo and olestra groups, respectively, at week 6 .
Relative to placebo, serum 25-hydroxy$D_{2}$ levels were approximately $20 \%$ lower in the olestra group after two, four and six weeks. Serum levels of 25 . hydroxy-D 3 were not affected by olestra consumption.

Since dietary vitamin $D$ accounts for about $10 \%$ of the total pool, the effect of $18 \mathrm{~g} /$ day olestra on dietary vitamin D absorption would not have a meaningful effect on total vitamin D status. The controlling factor in determining vitamin D status is the production of vitamin $D_{3}$ by the skin as a result of sunlight exposure. This was confirmed in a 16 week study without vitamin D supplementation, which showed no difference in serum levels of vitamin D (BP Koonsvitsky, Procter \& Gamble, unpublished data).

The effect of olestra on vitamin $\mathrm{K}$ status was also investigated in the sixweek study described above (41) using a sensitive measure of vitamin $\mathrm{K}$ status, the serum concentration of functional prothrombin, measured by the Simplastin-Ecarin assay (42). Clotting times and serum phylloquine concentrations were also measured.

There was no significant difference between groups in levels of functional prothrombin measured by the Simplastin-Ecarin ratio; values were 0.80 and 0.79 for the olestra and placebo groups, respectively, at baseline, and 0.81 for both groups at study end. There was no significant difference in change from baseline levels of serum phylloquinone when analyzed by repeated measures. Prothrombin time and partial thromboplastin time were unchanged over the course of the study and unaffected by olestra. The results indicate that chronic ingestion of olestra at $20 \mathrm{~g} /$ day in the diet does not affect vitamin $\mathrm{K}$ status. Since there are very limited stores of vitamin $\mathrm{K}$ and diet records showed low levels of vitamin $\mathrm{K}$ intake, this study was a sensitive test of effects of olestra on vitamin $\mathrm{K}$ status.

Human clinical tests have shown that olestra in the diet has little or no effect on plasma vitamin A levels (39; EJ Schaeffer, Tufts University, unpublished data). A small base-size study showed no significant reduction in plasma vitamin A levels when the vitamin was dissolved in olestra ( $18 \mathrm{~g}$ in a milk shake) prior to ingestion. However, humans have large hepatic stores of vitamin A and thus plasma concentrations do not readily reflect changes in absorption. Additional studies are in progress to provide data on the potential of olestra to affect vitamin A stores.

\section{DRUG ABSORPTION}

Studies were also conducted in rats and humans which showed that olestra did not affect absorption of lipophilic drugs. The drugs tested included propranolol and the oral contraceptives, norethindrone and ethynyl estradiol, which are among the most lipid soluble. Diazepam (Valium; Roche) was also tested because it is widely used. In one human study each drug being tested was taken in a milk shake made with either $16 \mathrm{~g}$ olestra, $16 \mathrm{~g}$ corn oil, or water. The results showed no difference in amount absorbed or in time to peak serum levels (43). Another placebo controlled crossover study which monitored 28 women over two menstrual cycles showed that olestra at $18 \mathrm{~g} /$ day did not affect the absorption or efficacy of a low dose oral contraceptive (Lo/Ovral-28; Wyeth) (44).

\section{ABSORPTION OF OTHER COMPOUNDS}

Halogenated hydrocarbons are among the most lipophilic of xenobiotic substances and would therefore be predicted to interact strongly with olestra. Dietary olestra has been shown to markedly reduce the absorption of an example of this class of compounds, 2,2-bis (p-chlorophenyl) 1,1,1-trichloroethane (DDT), in animals. As in the case of cholesterol, olestra reduced the absorption of both dietary and 'endogenous' DDT that had been stored in the body from prior feeding. Based on lymphatic collection of ${ }^{14} \mathrm{C}$. labelled DDT, replacement of $50 \%$ of the dietary soybean oil with olestra decreased dietary DDT absorption to $21.0 \pm 2.4 \%$ from $66.6 \pm 1.9 \%$ in the rat (44). In a study of previously deposited ${ }^{14} \mathrm{C}$-labelled DDT in gerbils, the excretion of ${ }^{14} \mathrm{C}$ increased two- to threefold when olestra was included as $10 \%$ of 
the diet (46). Combined with partial food restriction, olestra effected an up to eightfold increase in excretion of the label. These results are consistent with the dissolution of DDT and its lipophilic metabolite into the intestinal olestra phase, thereby reducing their absorption and reabsorption. Food restriction apparently mobilized these substances from adipose storage sites.

\section{CONCLUSIONS}

Results of extensive research show that olestra is essentially inert in the gastrointestinal tract, affecting neither morphology nor function. It is not hydrolyzed by gastric or pancreatic lipases and is therefore not absorbed. It is

\section{REFERENCES}

1. Eisenberg S. High density lipoprotein metabolism. J Lipid Res

1984;25:1017-58.

2. Hauton JC, Domingo N, Mortigne M, et al. A quantitative dynamic concept of the interphase partition of lipids: Application to bile salt-lecithincholesterol mixed micelles. Biochimie 1986;68:275-85.

3. Kuksis A. Fat Absorption, vols I, II. Boca Baton: CRC Press, 1986.

4. Shiau Y-F. Lipid digestion and absorption. In: Johnson LR, ed. Physiology of the Gastrointestinal Tract. New York: Raven Press, 1987.

5. Thomson ABR, Keelan M, Garg ML, Clandinin MT. Intestinal aspects of lipid absorption: In review. Can J Physiol Pharmacol 1989;67:179-91.

6. Tso P, Simmonds WJ. The absorption of lipid and lipoprotein synthesis. Lipid Res Methodol 1984;VOL:191-216.

7. Tso P. Gastrointestinal digestion and absorption of lipid. In: Paoletti R, Kritchevsky DR, eds. Advances in Lipid Research. New York: Academic Press Inc, 1985.

8. Vance DE, Vance JE. Biochemistry of lipids and membranes. Toronto: The Benjamin Cummings Publishing Co Inc, 1985

9. Watkins JB. Lipid digestion and absorption. Pediatrics 1985;751:151-6.

10. Dietschy JM, Wilson JD. Regulation of cholesterol metabolism 1. N Engl ] Med 1970;282:1128-38.

II. Dietschy JM, Wilson JD). Regulation of cholesterol metabolism 2. N Engl J Med 1970;282:1179-83.

12. Dietschy JM, Wilson JD. Regulation of cholesterol metabolism 3. N Engl J Med 1970;282:1241-9.

13. Mattson FH, Volpenhein RA. also not metabolized by colonic microflora. Studies of gastric emptying, bile acid physiology and pancreatic response indicate that olestra does not affect these functions. Neither does it alter the normal digestion and absorption of macronutrients, minerals or lipophilic drugs. The absorption of cholesterol and fat-soluble vitamins, however, can be affected to an extent determined by the amount of olestra, the lipophilicity of the nutrient and other factors. Clinical research to date indicates that olestra $18 \mathrm{~g} /$ day decreases serum vitamin E levels to levels still within normal ranges, but does not affect vitamin $D$ or $K$ status. Other studies are assessing the effects of

Hydrolysis of fully esterified alcohols containing from one to eight hydroxy groups by the lipolytic enzymes of rat pancreatic juice. J Lipid Res 1972;13:325-8.

14. Mattson FH, Nolen GA. Absorbability by rats of compounds containing from one to eight ester groups. I Nutr 1972;102:1171-6.

15. Matrson FH, Volpenhein RA. Rate and extent of absorption of the fatty acids of fully esterified glycerol, erythritol, xylitol, and sucrose as measured in thoracic duct cannulated rats. J Nutr 1972;102:1177-80.

16. Bernhardt CA. Olestra-A non-caloric fat replacement. Food Technol Int 1988:176-8

17. Fallat RW, Glueck CJ, Lutmer R, Mattson FH. Short-term study of sucrose polyester, a nonabsorbable fat-like material as a dietary agent for lowering plasma cholesterol. Am J Clin Nutr 1976;29:1204-15.

18. Glueck CJ, Mattson FF, Jandacek RJ. The lowering of plasma cholesterol by sucrose polyester in subjects consuming diets with 800,300 or less than $50 \mathrm{mg}$ of cholesterol per day. Am J Clin Nutr 1979;32:1636-44.

19. Wood FE, Hollenbach EJ, Kaffenberger RM. Lack of absorption of olestra (OL) following chronic feeding to rats and monkeys. Fond Chem Toxicol 1991;29:231-6.

20. Wood FE, Tierney WJ, Knezevich AL, Bolte HF, Maurer JK, Bruce RD. Chronic toxicity and carcinogenicity studies of olestra in Fischer 344 rats. Food Chem Toxicol 1991;29:223-30.

21. Nolen GA, Wood FE, Dierckman TA. A two-generation reproductive and developmental toxicity study of sucrose polyester. Food Chem Toxicol 1987;25:1-8. olestra on vitamin A stores to determine the appropriateness of supplementation.

There is increasing evidence that high intakes of fat, especially saturated fat, increase the risk of cardiovascular disease, and excess dietary fat is a contributing factor in obesity, hypertension, adult onset diabetes, and probably some types of cancer. The use of olestra and other fat replacers has the potential to help reduce the percentage of calories from fat and, importantly, the amount of saturated fat in the diet, by increasing the availability of highly acceptable, frequently eaten foods that are lower in fat but retain the same taste and texture as full-fat counterparts.

22. Adams MR, McMahan MR, Mattson $\mathrm{FH}$, Clarkson TB. The long-term effects of dietary sucrose polyester on African green monkeys. Proc Soc Exp Biol Med 1981;167:346-53.

23. Miller KW, Wood FE, Stuard SB, Alden CL. Twenty month olestra feeding study in dogs. Food Chem Toxicol. (In press)

24. Jandacek RJ. The effect of nonabsorbable lipids on the intestinal absorption of lipophiles. Drug Metab Rev 1982;13:695-714.

25. Cortot A, Phillips SF, Malagelada JR. Gastric emptying of liquid after ingestion of a solid-liquid meal in humans. Gastroenterology 1981;80:922-7.

26. Cortot A, Phillips SF, Malagelada JR. Parallel gastric-emptying of nonhydrolyzable fat and water after a solid-liquid meal in humans. Gastroenterology 1982;82:877-81.

27. Hastings $\mathrm{MH}$, Schneeman $\mathrm{BO}$. Pancreatic enzyme and plasma cholesterol response to chronic ingestion of a nonabsorbable lipid in rats. Inst Nutr 1986;7:2372-7.

28. Mattson FH, Jandacek RJ, Webb MR. The effect of a nonabsorbable lipid, sucrose polyester, on the absorption of dietary cholesterol by the rat. J Nutr 1976;106:747-52.

29. Jandacek RJ, Mattson FH, McNeely S, Gallon L, Yunker R, Glueck CJ. Effect of sucrose polyester on fecal steroid excretion by 24 normal men. Am J Clin Nutr 1980;33:251-9

30. Glueck CJ, Jandacek RJ, Subbiah MTR, et al. Effect of sucrose polyester on fecal bile acid excretion and composition in normal men. Am J Clin Nutr 1980;33:2177-80.

31. Crouse JR, Grundy SM. Effects of sucrose polyester on cholesterol 
metabolism in man. Metabolism 1979;28:994-1000.

32. Grundy SM, Anastasia JV, Kesaniemi YA, Abrams J. Influence of sucrose polyester on plasma lipoproteins, and cholesterol metabolism in obese patients with and without diabetes mellitus. Am J Clin Nutr 1986;44:620-9.

33. Nuck BA, Federle TW. Inability of the human colonic microflora to metabolize olestra. American Society for Microbiology, 1990; $\# 073: 275$. (Abst)

34. Jandacek RJ, Ramirez MM, Crouse JR. Effects of partial replacement of dietary fat by olestra on dietary cholesterol absorption in man. Metabolism 1990;39:848-52.

35. Mattson FH, Hollenbach EJ, Kuehlthau CM. The effect of a nonabsorbable fat, sucrose polyester, on the metabolism of vitamin A by the rat. J Nutr 1979;109:1688-93.

36. Glueck CJ, Hastings MM, Allen C, et al. Sucrose polyester and covert caloric dilution. Am J Clin Nutr
1982;35:1352-9.

37. Mellies MJ, Jandacek RJ, Taulbee JD, et al. A double-blind, placebocontrolled study of sucrose polyester in hypercholesterolemic outpatients. Am J Clin Nutr 1983;37:339-46.

38. Glueck C], Jandacek RJ, Hogg E, Allen C, Baehler L, Tewksbury M. Sucrose polyester: Substitution for dietary fats in hypocaloric diets in the treatment of familial hypercholesterolemia. Am J Clin Nutr 1983;37:347-54.

39. Mellies MJ, Vitale C, Jandacek RJ, Lamkin GE, Glueck CJ. The substitution of sucrose polyester for dietary fat in obese, hypercholesterolemic outpatients. Am J Clin Nutr 1985;41:1-12.

40. Jones DY, Miller KW, Koonsvitsky BP, et al. Serum 25-hydroxyvitamin D levels of free-living subjects consuming olestra. Am J Clin Nutr 1991;53:1281-7.

41. Jones DY, Miller KW, Koonsvitsky BP, et al. Vitamin K status of free-living subjects consuming olestra. Am J Clin
Nutr 1991;53:943-6.

42. Suttie JW, Mummah-Schendel LL, Shah DV, Lyle BJ, Greger JL. Vitamin $K$ deficiency from dietary vitamin $K$ restriction in humans. Am J Clin Nutr 1988;47:475-80.

43. Roberts RJ, Leff RD. Influence of absorbable and nonabsorbable lipids and lipid-like substances on drug bioavailability. Clin Pharmacol Ther 1989:45:299.304.

44. Miller KW, Williams DW, Carter SB, Jones MB, Mishell DR. The effect of olestra on systemic levels of oral contraceptives. Clin Pharmacol Ther 1990;48:34-40.

45. Volpenhein RA, Webb DR, Jandacek R]. Effect of a nonabsorbable lipid, sucrose polyester, on the absorption of DDT by the rat. J Toxicol Environ Health 1980;6:679-83.

46. Mutter LC, Blanke RV, Jandacek RJ, Guzelian PS. Reduction in the body content of DDE in the Mongolian gerbil treated with sucrose polyester and caloric restriction. Toxicol Applied Pharmacol 1988;92:428-35. 


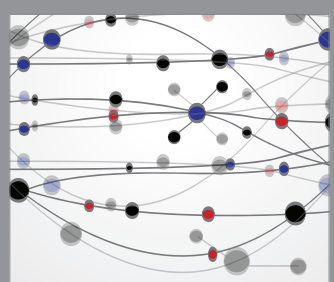

The Scientific World Journal
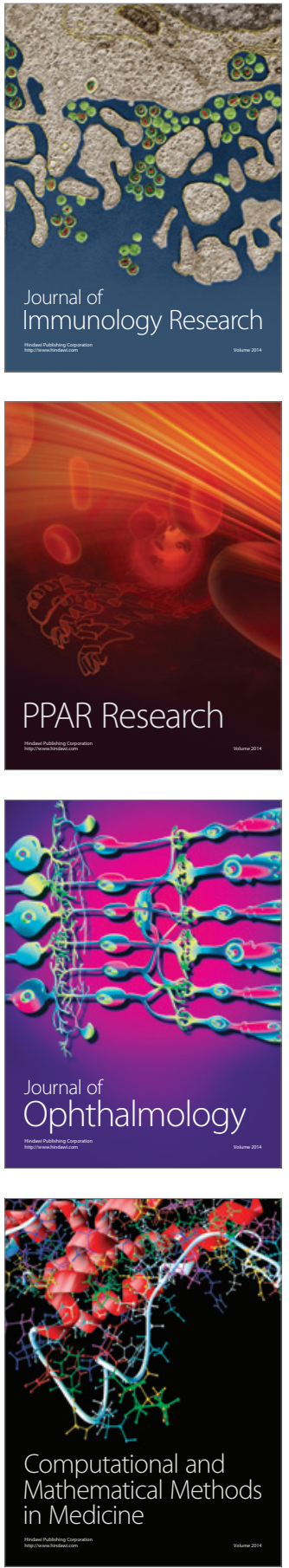

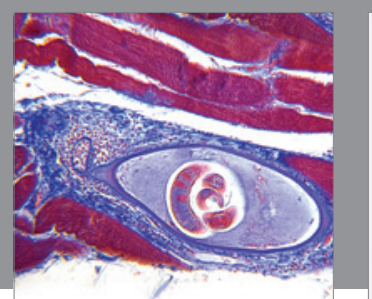

Gastroenterology Research and Practice

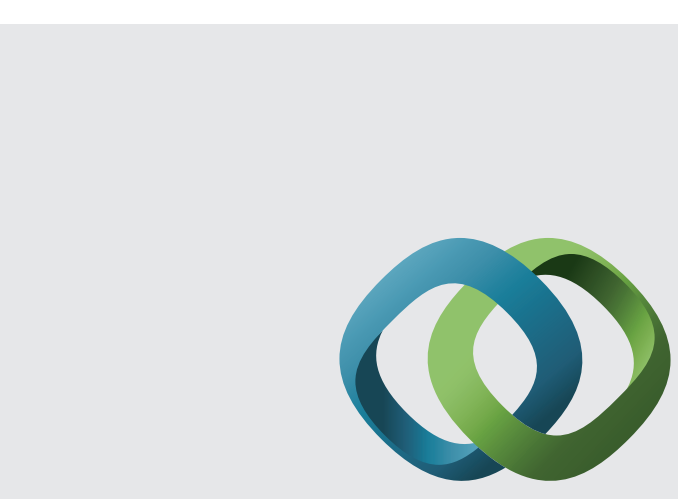

\section{Hindawi}

Submit your manuscripts at

http://www.hindawi.com
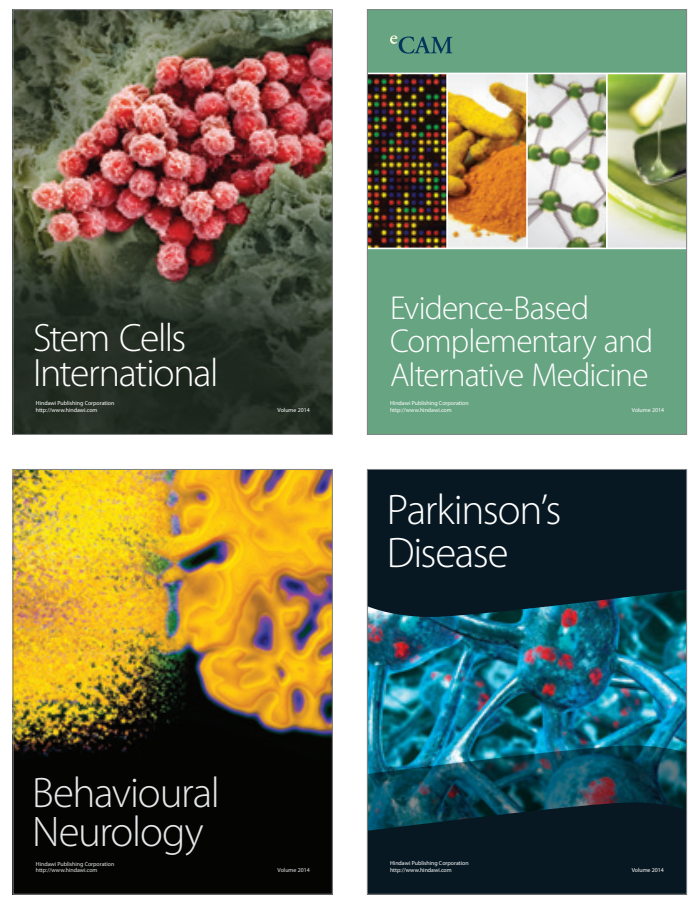
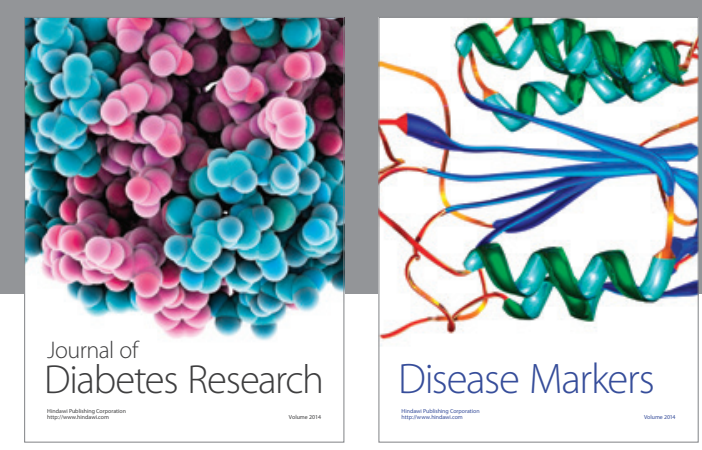

Disease Markers
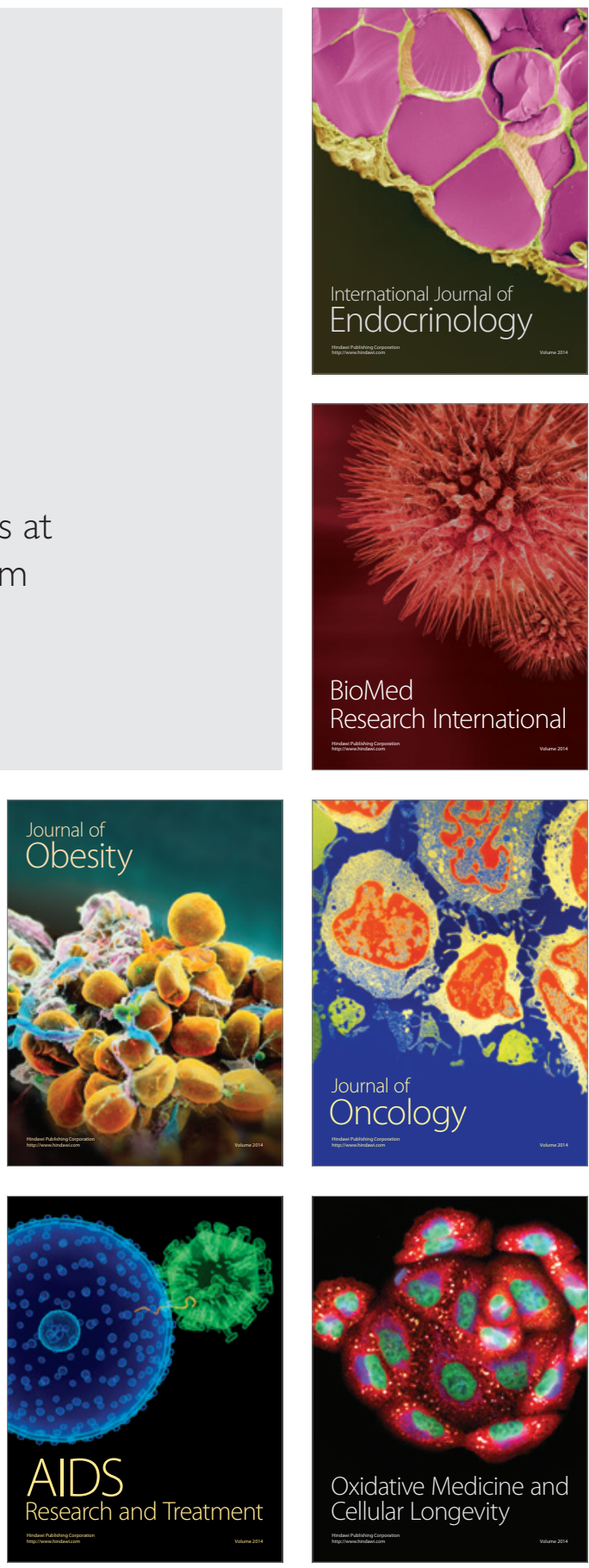